\title{
Evidence of an Eleventh-Century AD Cola Nitida Trade into the Middle Niger Region
}

\author{
Nikolas Gestrich (D) Louis Champion • \\ Daouda Keïta $\cdot$ Nafogo Coulibaly • \\ Dorian Q. Fuller
}

Accepted: 7 June 2021 / Published online: 5 July 2021

(C) The Author(s) 2021

\begin{abstract}
Kola nut (Cola cf. nitida) and Safou fruit (Dacryodes edulis) remains have been discovered in eleventh- to fourteenth-century archaeological contexts at Togu Missiri near Ségou in Mali. These remains are evidence of early trade in perishable foodstuffs from the West African forest zone into the Middle Niger region. On the basis of these finds, this paper argues that long-distance trade links were well
\end{abstract}

N. Gestrich $(\bowtie)$

Frobenius Institute, Goethe University, Frankfurt am Main, Germany

e-mail: gestrich@uni-frankfurt.de

L. Champion

Laboratoire Archéologie Et Peuplement de L'Afrique (APA), Anthropology Unit, Department of Genetics and Evolution, University of Geneva, Geneva, Switzerland

D. Keïta

Musée National du Mali, Bamako, Mali

N. Coulibaly

Institut Des Sciences Humaines du Mali, Bamako, Mali

D. Q. Fuller

Institute of Archaeology, University College London, London, UK

D. Q. Fuller

School of Cultural Heritage, Northwest University, Xi' an, China

D. Q. Fuller

Department of Archaeology, Max Planck Institute for the Science of Human History, Jena, Germany established by the end of the first millennium AD. It thereby supports the hypothesis that dates the inception of trade between the West African forest zone and the savanna regions to the first millennium AD. The circumstances of the find are discussed, as are the implications for our understanding of the wider exchange network based on the Niger River system in the late first and early second millennium CE.

Résumé Des fragments de noix de cola (Cola cf. nitida) et de fruits de Safou (Dacryodes edulis) ont été découverts dans des niveaux archéologiques du onzième au quatorzième siècle à Togu Missiri près de Ségou au Mali. Ces vestiges témoignent d'un commerce précoce des denrées périssables de la zone forestière d'Afrique occidentale vers la région du Moyen Niger. Sur la base de ces découvertes archéologique, cet article montre que les liens commerciaux à longue distance entre la zone forestière d'Afrique de l'Ouest et de la région des savanes étaient déjà bien établis dès la fin du premier millénaire $\mathrm{AD}$. Les contextes et la nature de cette découverte sont discutés, ainsi que les implications sur notre compréhension du réseau d'échange basé sur le haut et moyen Niger à la fin du premier et au début du deuxième millénaire de notre ère.

Keywords Kola nut - African plum - Stimulants · West African archaeology · Archaeobotany $\cdot$ Mali 


\section{Introduction}

Kola nuts (the seeds of Cola nitida or Cola acuminata) are important to West African cultures past and present. These seeds contain caffeine, theobromine, and kolanin, among other bioactive phenolic compounds (Niemenak et al., 2008; Nyadanu et al., 2020). In recent times, they have been essential as gifts for almost any social occasion. They accompany visits, negotiations, reconciliations, and many other events, where they are given as a sign of respect or goodwill or as a form of symbolic payment. Kola nuts also feature centrally in divination and sacrifices and are valued as mild stimulants that suppress hunger and thirst (Lovejoy, 1995; Sundström, 1966). Their cultural uses and symbolism are fairly well described for the forest zone (Drucker-Brown, 1995; Hauenstein, 1974; Kwame, 2019) but less explicitly so for the western Sahel, where they are a constant yet peripheral feature in ethnographic accounts (Bertaux, 1984; Boujou, 2000). Although they are highly valued culturally, kola nuts do not grow in the Sahel. Instead, they come from the West African forest zone, a fact which has even led to the cardinal direction south becoming named after kola nuts in several Sahelian Mandé languages. For example, the Bambara and Northern Maninkakan word for the "south" is "worodugu" — lit. "the land of kola."
The most common species of kola nuts in West Africa, and those responsible for the vast majority of consumed nuts, are Cola acuminata (Vent.) Schott et Endl. and Cola nitida (P.Beauv.) Schott et Endl. These two are the economically most important of more than 125 Cola species native to the West African forest zone (Burkill, 2000). The growing conditions of the trees prevent them from prospering in the drier climate north of the tropical forests (Fig. 1). Thus, large parts of West Africa in which kola nuts are regularly consumed lie outside of the areas where they can be grown, and so the nuts need to be moved to reach their consumers. The trade in kola nuts is considerable today, with a global production of 280,000 metric tons in 2016, of which Nigeria, the Ivory Coast, Cameroon, and Ghana produced $97 \%$ (Tridge, n.d.).

Despite their popularity as a trade item, kola nuts are not easy to transport. Since they must be kept moist, despite warm climatic conditions, and are susceptible to pests (Lovejoy, 1980, p. 97), they must be frequently unpacked, checked, watered, and repacked. Several authors have pointed out that trade in kola nuts (especially historical trade that did not rely on mechanized transport) must depend on established commercial networks so that the nuts can reach their destination before they are spoiled (Lovejoy, 1980, p. 106; Person 1968, p. 102). Even present-day kola
Fig. 1 Distribution of main production area for Cola nitida, Cola acuminata, and Dacryodes edulis (Lovejoy, 1980, Burkill, 2000) and the archaeological site (Togu Missiri) where Cola sp. and Dacryodes edulis fruit remains were recovered

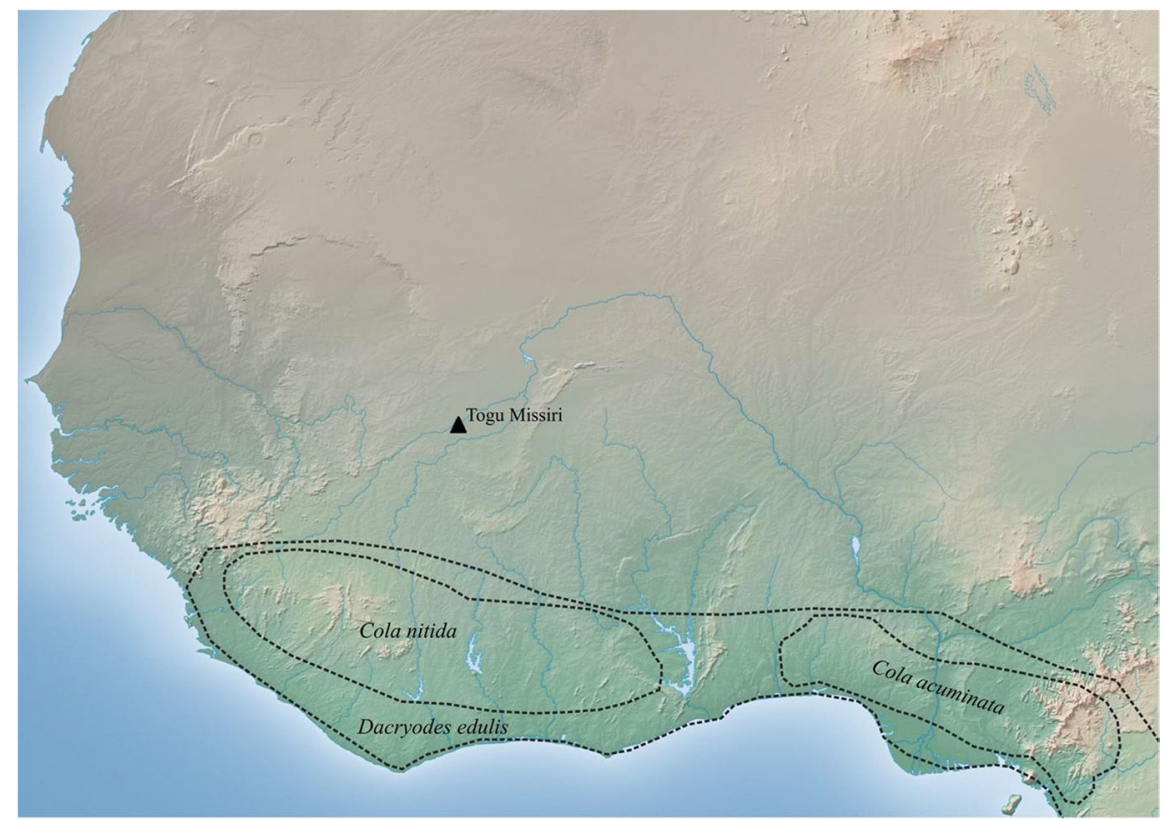


trade is seen as a high-risk venture, according to Kirikoshi (2019), who stresses the importance of trust relationships between the parties in this trade.

Kola nuts are thus a trade good that cannot be traded casually. They require carefully planned trading operations, established routes, high mobility, and close contact between persons over large geographical distances to minimize the risk of spoiling the merchandise. It may be due to this risk and these infrastructural demands that the profit margins were historically very high. Roberts (1987, p. 67) speaks of a gross profit of $400 \%$ for traders from the Ségou area in the eighteenth and nineteenth centuries, while a late nineteenth-century source speaks of a value increase of $6,000 \%$ on nuts bought in Ghana and sold near Lake Chad (Hopkins, 2016, p. 73). Between the long distances to be overcome and the risk of loss from spoiled commodity, the beginnings of this trade would have faced considerable obstacles. The question of when and under what circumstances such a trade began remains to be answered.

\section{Kola Trade and Trade Networks in Middle Niger During the First and Second Millennia AD}

Lovejoy's (1980) study on the interior regions provides the most comprehensive overview of the historical, ethnographic, and linguistic evidence for the development of the West African kola trade to date (also see Brooks, 1980, for the treatment of the coastal kola trade). He claims that the market for kola existed in the savanna by the thirteenth century and proposes, though without firm evidence, that it might have been established much earlier than that. There are several indications that kola nuts are a product that must have been traded following a long formative period of exchange relationships, which allowed the kola nut to gradually gain popularity in the Sahel. Firstly, the perishable nature of the nuts means they must be transported quickly or traders risk losing their cargo. Hence, routes with safe and fast passage must be known and negotiated in advance. Secondly, the linguistic evidence of widely shared names across many languages suggests that kola nuts became available in the savanna and Sahel zones within a short period, rather than through a lengthy, gradual spread
(Lovejoy, 1980, p. 106). This contrasts with the evolved cognates shared across Benue-Congo languages and basal Bantu that presumably originated in the forest zone (Bostoen, 2014). Thirdly, Lovejoy (1980, p. 100) points out that kola nuts are an acquired taste, which means that a market for them had to be created. This sets them apart from many other historical West African trade items like salt, sandstone implements, iron, cloth, or grain which are arguably more fundamental to human needs. In this regard, a lengthy period of contact must have existed between the Sahel/ savanna and the rainforest zones before a regular trade in kola nuts could be established. While the evidence presented in this paper is the earliest for kola nuts in the savanna zone so far, it probably does not date the beginning of the kola trade, and it is definitely later than the beginning of trade relationships between the forest and savanna zones.

Much of the existing literature ties the beginnings of the forest-savanna trade to gold. This is, for instance, the case with Nehemia Levtzion, who saw contacts between the savanna and the forest areas as an effect of political developments driven by the gold trade. Levtzion (1973, p. 53) supposed that the political succession from the Empire of Ghana to Sosso and then to the Empire of Mali implies a progressive movement of the centers of power southward from the desert edges towards the forest zone, although the accuracy of this orthodox version of West Sudanese history has been questioned (Gestrich, 2019; Hunwick, 1973; MacDonald et al., 2018). Corollaries of this shift, he believes, are that the Bure goldfields gained importance and that the populations in the forest zone were drawn into the pre-existing long-distance trade networks of the savanna. This would date the inception of regular trade links to the early fourteenth century. Paradoxically, Levtzion states elsewhere (1973, p. 181) that the use of kola nuts was well established in the savanna by then and that it "already fulfilled many of its more recent economic and social functions" during the period of the "great empires." Certainly, the fourteenth-century date for the inception of the kola nut trade appears to be late since we have documentary records that suggest the inclusion of kola nuts in the trans-Saharan trade before 1356 (al-Maqqarī in Levtzion \& Hopkins, 2000, p. 307). 
R. McIntosh sees a similar link to gold as a driver of north-south trade, though he believes this trade began considerably earlier, by the middle of the first millennium AD. For R. McIntosh, the kola and gold trades are a southern add-on to earlier networks that brought iron, sandstone objects, and salt into the Inland Niger Delta in exchange for foodstuffs and led to specialized and regular trading expeditions (McIntosh, 1998, p. 217). All of these relate to the broader economic connections in the West African savanna and the Sahel, for which archaeological research is increasingly showing that a high-volume trade over medium to long distances developed in the mid to late first millennium. The existence of such interregional trading networks has been mostly documented in iron (Gestrich, 2013; Gestrich \& MacDonald, 2018; Håland, 1980; McIntosh, 1995; Serneels \& Perret, 2003) and likely also extends to foodstuffs, salt, sandstone, and charcoal. The main drivers of this trade are the diversity in ecological zones and regional variations in geology, which govern the distribution of plants, animals, and mineral resources such as iron ore, salt, and sandstone. These regional ecological and geological contrasts mean that many areas are abundant in a particular set of vital resources while lacking others. If we suppose Levtzion's and McIntosh's proposals for the connection between gold and kola trades to be accurate, we might suggest that the kola trade developed before the seventh or eighth century since this is when we have the earliest written mentions and earliest archaeological evidence for the trans-Saharan gold trade (Nixon, 2017, p. 157-160). In this context, it is also worth mentioning Brooks' (1993) work on the early expansion of pre-European contact trade networks, in which he also links kola and gold as major factors in the rise of Mandé-speaking populations to political power and their demographic expansion. Brooks, however, sees this trade as developing in response to a southward shift in climatic zones around 1100 .

In historical linguistics, names for kola are reconstructible to considerable time depths. Williamson (1993) showed that terms for kola could be reconstructed in many West African proto-languages. A root that occurs in Benue-Congo languages in Nigeria and Cameroon is shared with Proto-Bantu and reconstructed to *-bèdú (Blench, 2006; Bostoen, 2014). The term góóró from Songhay appears to have been spread by Hausa traders later (Blench, 2006). Lovejoy's
(1980) reconstruction of the linguistic evidence shows considerable diversity in words for kola nuts in the languages of the forest zone. By contrast, the terms for kola in the savanna from the Atlantic coast to Lake Chad virtually all use a variation of goro or woro, indicating that they are borrowed from a West Atlantic language in the Sierra Leone-Guinea border area, where the Niger has its headwaters. Although the kola nut was undoubtedly known throughout the forest zone, it therefore seems to have been this area from where its commercialization and trade into the savanna began. This linguistic evidence also suggests that none of the other growing areas traded north sufficiently early to influence the vocabulary of the savanna peoples, who had settled on the * goro root before areas like the Akan region became involved in the trade. When exactly the first regular trade links to the latter area developed is currently impossible to say. However, the Gonja region of north central Ghana seems to have been involved in trade with the savanna, possibly the Inland Niger Delta, by the twelfth century $\mathrm{AD}$, as the presence of African rice (Oryza glaberrima) at Old Buipe indicates (Champion in Genequand et al., 2020), and thus, earlier than Wilks (1961) had previously suggested.

Thus, the extant literature documents the establishment of regular trade routes linking the West African forest zone with the savanna and the desert edge sometime between the mid-first millennium and the early second millennium AD. Through these networks, which might have initially developed for gold trade, kola nuts began to be traded into the savanna and even across the Sahara. The initial trade seems to have focused on the source areas of the Niger river in today's Sierra Leone-Guinea border region, but it subsequently developed across several areas in the forest zone, where kola trees were also known and grown. From the outset, the trade in kola nuts required well-known routes, at least part-time specialized traders, and social contacts spanning large distances. From the beginning of the second millennium AD, Togu Missiri near Ségou in Mali was part of this trade network.

\section{The Maraka Settlement of Togu}

Togu is today a large village on an unpaved road linking the city of Ségou to the market town of Dioro. It 
consists of a recent sprawling settlement and an older core beside a large pond, which is seasonally fed from the canals of the neighboring irrigation scheme, the Opération Riz Ségou (see Fig. 2). During the time of the Segu fanga, a polity founded in the early eighteenth century by "Biton" Mamari Coulibaly and effectively ended by El-hajj Umar Tall's conquest in 1860, Togu was one of the major marakadugu, settlements of the Maraka group. The Maraka were, and are, understood as a contrast to the majority Bamana group (Bazin, 1972, 1985) and engaged in activities that were not part of Bamana lifestyle, most significantly the practice of Islam, the refusal to take part in warfare, and an engagement in long-distance commerce. The marakadugu are the focus of a research program which aims to understand the settlement and population dynamics in the area between the Niger and the Bani before the eighteenth century. Together with the Traoré lineages (Bazin, 1988), they play a key role in local histories preceding the Segu fanga. Their origins are controversial and their age was formerly unknown. Nevertheless, previous authors have seen them as a key enduring part of an ancient settled landscape (MacDonald \& Camara, 2011) and sociopolitical system (Bazin, 1972, 1988). Although they were politically sidelined, they were not removed in the demographically and politically turbulent developments of the fanga period and continued to be of commercial and religious importance. Our ongoing project has carried out archaeological surveys and excavations as well as extensive interviews on local traditions in an attempt to gain a multiperspective understanding of the past of the Maraka and their neighboring communities. This undertaking brought team members to Togu on several occasions between 2016 and 2020.

As Richard Roberts (1987) has described for Sinzani, one of the main Maraka centers of trade and
Fig. 2 Location of the site below the eastward turn of the Niger at Markala (archaeological sites of the area are shown in black)

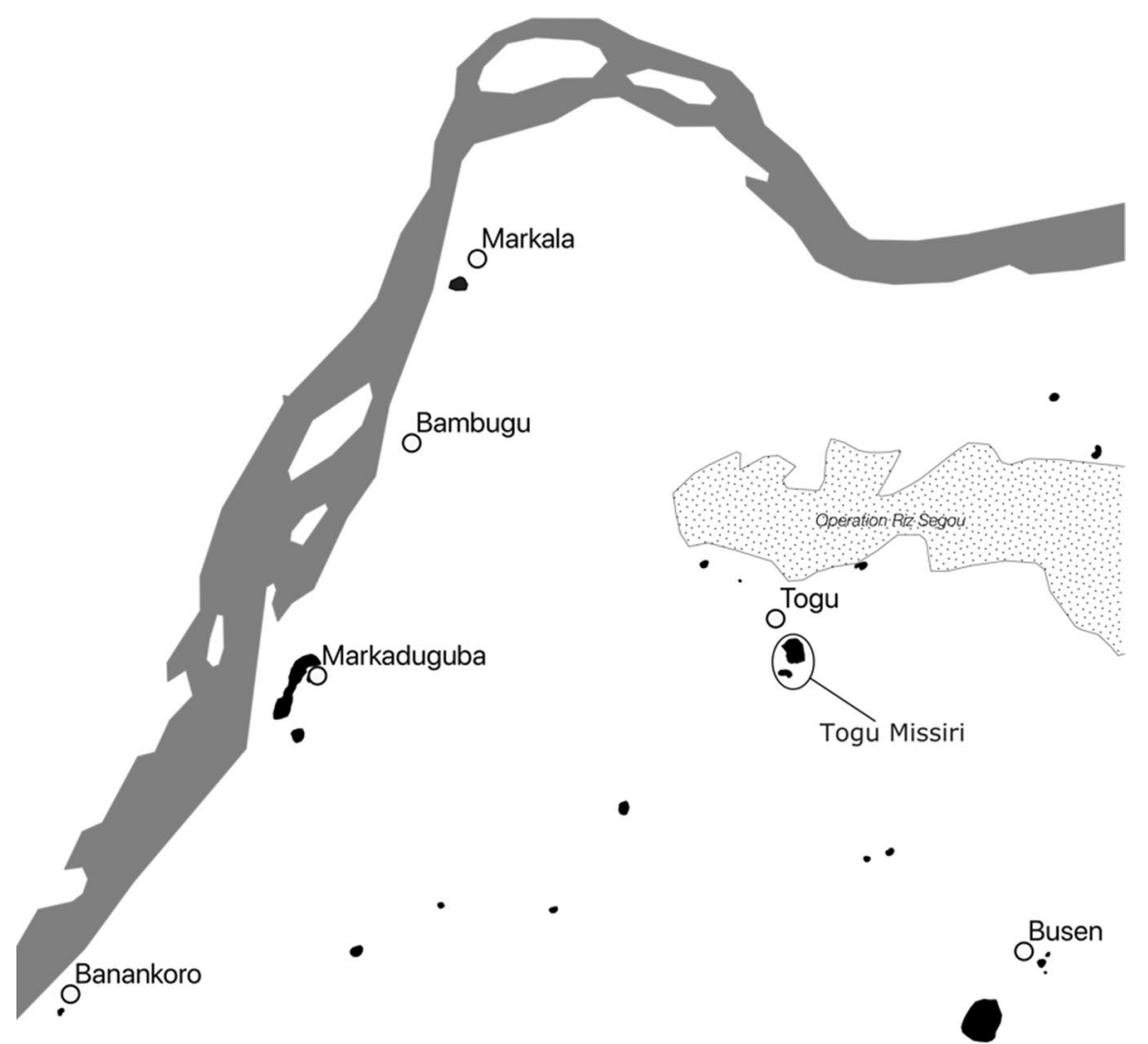


production in the Segu fanga, the Maraka commercial activities took several forms. Instead of trading in the market, the Maraka of Sinzani mainly acted as brokers (jatigi) to Azawagh Arab (Suraka) traders bringing salt from the north, in exchange primarily for slaves, which the Segu fanga supplied in large numbers. Yet, there was also a southern component of this trade, based entirely on foodstuffs, in which Maraka traders were directly involved. According to our informants in the region, salt, dried fish, and sunbala (a condiment made from the fermented pods of the nغ̀re tree - Parkia biglobosa) were carried south on donkeys as far as Man, Bouaké, and Abidjan in Cote d'Ivoire (see Fig. 3) until recently. The traders returned with kola nuts and cloth. In the first detailed French reports on Ségou in 1893/1894, Togu is listed as a staging point for caravans going towards the southeast, crossing the Bani, and from there taking many different directions (ANOM 51 PA 1).

Our surveys in 2016 revealed four archaeological site complexes surrounding the present village of Togu - three habitation sites and one small iron smelting site (Gestrich \& Keita, 2017). We focused our attention on the site known as "Togu Missiri," which translates as "mosque (or, the meeting place) of Togu." The town notables that we interviewed in the course of our research believe this to be the first of the settlements at Togu and that it was inhabited by one of the founding lineages of the Jire patronym.

\section{The Site of Togu Missiri}

Togu Missiri consists of a cluster of thirteen settlement mounds, seemingly in two distinct areas (Fig. 4). The mounds are most likely the remains of a single settlement, with the lower-lying areas between them representing seasonal ponds, open spaces, and roadways. The height of the mounds varies between 1.5 and $3.0 \mathrm{~m}$. The excavations carried out in January and December 2017 targeted the larger northern part of the site and tested one of the higher mounds, Mound G. Here, a 3- $\times-3-\mathrm{m}$ test trench aimed at gaining an overview of the stratigraphy and dates of the settlement was excavated to a depth of around $3 \mathrm{~m}$ below surface. The excavations, led by Daouda Keita, uncovered a sequence of layered earth and mud-brick buildings, floor levels, and midden deposits subdivided into four phases (Gestrich \& Keita, 2017). The sequence was dated with five AMS dates on wood charcoal between the early ninth and the late thirteenth century (Table 1).

In terms of material culture, Togu Missiri is comparable to other sites investigated in the area in recent years, mainly Sorotomo (MacDonald et al., 2011),
Fig. 3 Map of locations mentioned in the text

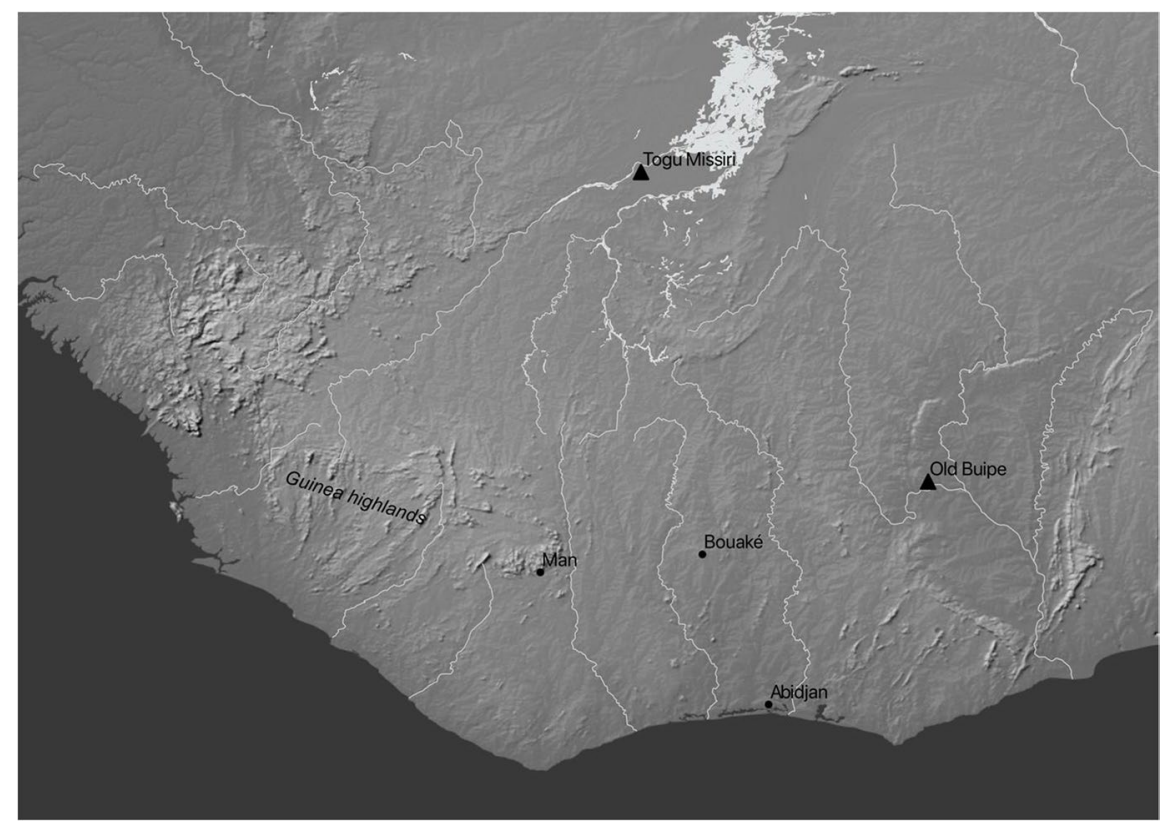




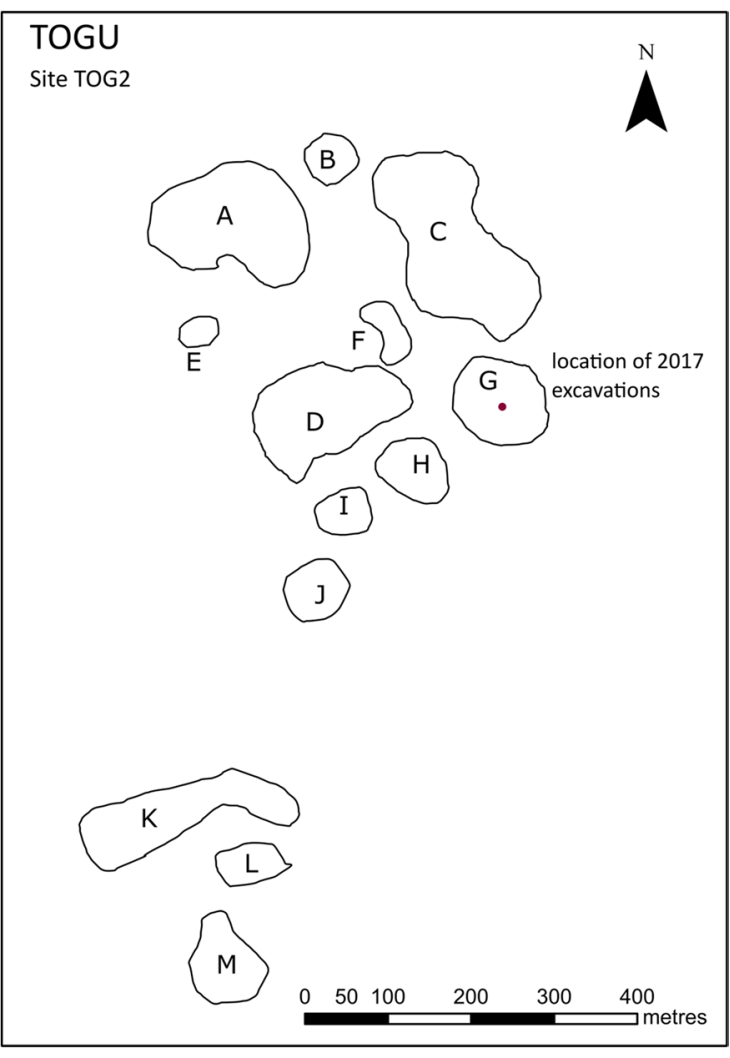

Fig. 4 Map of the individual settlement mounds at Togu Missiri, showing the location of the 2017 excavations

Marakaduguba, and Faraku. A combination of rectilinear and curvilinear construction in mud-brick and coursed earth, tamped laterite gravel floors, and pottery decorated with folded strip roulettes, fish spine roulettes, red slip, and burnish are among the typical elements of the archaeology of this region in the first half of the second millennium AD. Overall, the material culture of this settlement was not significantly different from the contemporaneous ones in the region. What was remarkable at Togu Missiri was the number of midden deposits uncovered by the excavations. These mostly consisted of soils with a high amount of ash and organic admixture which were rich in finds. There were pit features containing such midden deposits as well as midden layers between the occupation levels of the site (see Fig. 5). In the other sites that have been excavated in the area, no such deposits were found, with the possible exception of a deep pit feature at Sorotomo Unit B (MacDonald et al., 2011). The reason why our excavation trench at Togu Missiri had such an exceptional amount of midden material cannot so far be explained, nor do we know whether this is a feature of the site in general rather than only of the small area selected for test excavations.

\section{The Botanical Assemblage}

The soil samples analyzed for this study came from midden deposits (nine samples), from the sediment found inside intact pottery vessels (seven samples), and from living floors (two samples). They do not represent a systematic sample of the site, but all major architectural rebuilding phases are represented. The soil samples were subjected to bucket flotation and subsequently passed through a $0.25-\mathrm{mm}$ mesh sieve by the students of Bamako University's HOPE laboratory under the supervision of Nikolas Gestrich and N'Ji Jacques Dembélé. The samples were analyzed in London and Frankfurt by Louis Champion following the methodology described in Champion and Fuller (2019). Three samples were devoid of any plant remains. In total, 1425 archaeobotanical items were recovered from $100 \mathrm{~L}$ of soil. The density of finds,
Table 1 Radiocarbon dates from Togu Missiri

\begin{tabular}{llllll}
\hline Sample no & Site & Context & $\begin{array}{l}\text { Depth below } \\
\text { datum }(\mathrm{cm})\end{array}$ & BP & $95.4 \%$ cal AD \\
\hline Beta-464271 & TOG2 & 5 & 29 & $780 \pm 30$ & $\begin{array}{l}1,210-1,281 \\
(68.4 \%) 1,117-1,222\end{array}$ \\
Beta-464267 & TOG2 & 13 & 90 & $880 \pm 30$ & $\begin{array}{l}(27 \%) 1,042-1,104 \\
\text { Beta-464272 }\end{array}$ \\
Beta-502929 & TOG2 & 20 & 116 & $900 \pm 30$ & $1,039-1,210$ \\
& TOG2 & 42 & 235 & $1,140 \pm 30$ & $(78.6 \%) 854-981$ \\
Beta-502928 & TOG2 & 50 & 257 & $1,140 \pm 30$ & $(78.6 \%) 854-981$ \\
& & & & & $(11.3 \%) 802-848$ \\
\hline
\end{tabular}




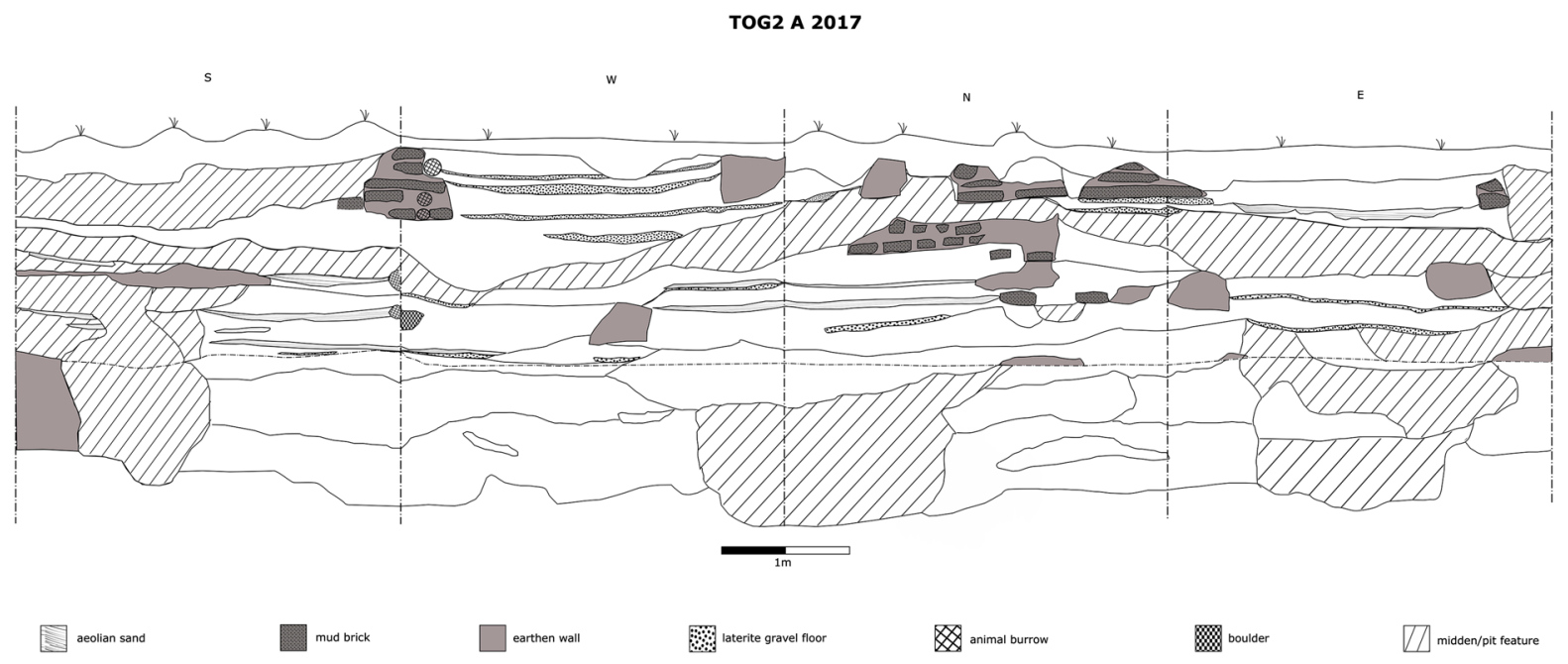

Fig. 5 Profiles of the excavations Togu Missiri showing midden deposits

14.3 botanical items per liter of soil, is high compared to other sites in the West African savanna and Sahel, where the average is around 10 botanical remains per liter of soil (Champion, 2019).

The archaeobotanical assemblage from Togu Missiri (Table 2) is largely dominated by fonio remains, of which 709 grains were found in 13 samples (72\% of ubiquity), representing a frequency of 54\%. Pearl millet is also well represented with 348 items (for $24 \%$ of the total assemblage [frequency]). Sorghum is present as well but only in low frequency (4\%). Finally, cowpea is present in very low frequency, with only three cowpea remains (less than $1 \%$ of the assemblage). With 37 remains (3\%), cotton is the main cash crop present.

One major diachronic development visible in the assemblage is the arrival of cotton, which is not present before around AD 1200 in Phase B. Further, a constant decrease in the frequency of pearl millet remains is noted (from $67 \%$ in Phase $\mathrm{E}$ to $7 \%$ in phase $\mathrm{B}$; Table 2). African rice is observed only in the earliest phase but only in a very small proportion $(2 \%$ in phase E) and is absent in other phases. These agricultural results will be further discussed in a separate publication. The focus here is on kola nut and safou fruit remains.

Like kola nuts, safou fruit trees, Dacryodes edulis, grow natively in the countries bordering the Gulf of Guinea but are cultivated (and naturalized) from Sierra Leone to Angola in the South and Uganda in the East (Fig. 1). The fruit is an ellipsoid drupe of $8-12 \mathrm{~cm}$ by $3-6 \mathrm{~cm}$ that usually supports one oblong seed up to $6 \mathrm{~cm}$ long. In Cameroon, where Safou is a daily staple, it is usually boiled in water and consumed as a side plate. It is usually the pulpy pericarp that is eaten, either raw or cooked. The pulp could also be reduced to a sort of butter. The seed kernel is also rich in oil and can be turned into butter (Bostoen, 2014; Burkill, 2000).

Kola nuts (Cola cf. nitida) and Safou fruits (Dacryodes edulis) (Fig. 6) are present in each soil sample from the last three phases (D, C, B) but are absent in the earliest phase. Cola nitida fruits are dry, woody capsules (or aphiscarum) that grow in radial clusters of two to six fruits (Fig. 6A). Inside the shell is a series of ovate to obturbinate seeds ("kola nuts") arranged in two rows. The seeds are threeor four-sided, with an indented hilum on the wider end, and often coming to point; in cross section, they are three- or four-sided. Pods of $\sim 10 \mathrm{~cm}$ long contain three to 14 seeds, which are reddish when fresh, $3 \mathrm{~cm}$ long, and surrounded by white fleshy aril. The $C$. nitida seed has a typical dicotyledonous structure, unlike $C$. acuminata with a seed that can split into three to six lobes (Dah-Nouvlessounon, et al., 2016; Niemenak et al. 2008). The specimens studied here have two cotyledons and are therefore referred to as Cola. cf. nitida (Fig. 6B, C), the species that is natural to the western side of the kola belt. Dacryodes edulis, the Safou or "African plum," 
Table 2 Archaeobotanical assemblage at Togu Missiri by phases: number of items recovered, frequency, and ubiquity for the main crops

\begin{tabular}{|c|c|c|c|c|c|}
\hline \multirow[b]{2}{*}{ Date AD } & \multicolumn{5}{|c|}{ Togu Missiri } \\
\hline & $\begin{array}{l}\text { Phase E } \\
900-1,000\end{array}$ & $\begin{array}{l}\text { Phase D } \\
1,000-1,100\end{array}$ & $\begin{array}{l}\text { Phase C } \\
1,100-1,200\end{array}$ & $\begin{array}{l}\text { Phase B } \\
1,200-1,300\end{array}$ & Total \\
\hline Number of samples & 3 & 5 & 5 & 5 & 18 \\
\hline Volume of soil in liters & 15 & 25 & 25 & 25 & 100 \\
\hline Digitaria exilis & - & 315 & 336 & 58 & 709 \\
\hline $\begin{array}{l}\text { Frequency } \\
\text { Ubiquity }\end{array}$ & & $\begin{array}{l}56 \% \\
75 \%\end{array}$ & $\begin{array}{l}59 \% \\
100 \%\end{array}$ & $\begin{array}{l}32 \% \\
100 \%\end{array}$ & $\begin{array}{l}54 \% \\
72 \%\end{array}$ \\
\hline $\begin{array}{l}\text { Pennisetum glaucum } \\
\text { Frequency } \\
\text { Ubiquity }\end{array}$ & $\begin{array}{l}72 \\
67 \% \\
100 \%\end{array}$ & $\begin{array}{l}161 \\
29 \% \\
100 \%\end{array}$ & $\begin{array}{l}103 \\
18 \% \\
100 \%\end{array}$ & $\begin{array}{l}12 \\
7 \% \\
75 \%\end{array}$ & $\begin{array}{l}348 \\
24 \% \\
89 \%\end{array}$ \\
\hline $\begin{array}{l}\text { Sorghum bicolor } \\
\text { Frequency } \\
\text { Ubiquity }\end{array}$ & $\begin{array}{l}3 \\
3 \% \\
33 \%\end{array}$ & $\begin{array}{l}14 \\
2.5 \% \\
100 \%\end{array}$ & $\begin{array}{l}35 \\
6 \% \\
100 \%\end{array}$ & - & $\begin{array}{l}52 \\
4 \% \\
67 \%\end{array}$ \\
\hline $\begin{array}{l}\text { Oryza glaberrima } \\
\text { Frequency } \\
\text { Ubiquity }\end{array}$ & $\begin{array}{l}2 \\
2 \% \\
33 \%\end{array}$ & - & - & - & $\begin{array}{l}2 \\
<1 \% \\
5 \%\end{array}$ \\
\hline $\begin{array}{l}\text { Vigna sp. } \\
\text { Frequency } \\
\text { Ubiquity }\end{array}$ & - & $\begin{array}{l}3 \\
<1 \% \\
40 \%\end{array}$ & - & - & $\begin{array}{l}3 \\
<1 \% \\
10 \%\end{array}$ \\
\hline $\begin{array}{l}\text { Gossypium sp. } \\
\text { Frequency } \\
\text { Ubiquity }\end{array}$ & - & - & - & $\begin{array}{l}37 \\
20 \% \\
75 \%\end{array}$ & $\begin{array}{l}37 \\
2 \% \\
22 \%\end{array}$ \\
\hline $\begin{array}{l}\text { Tree/bush (fruit) } \\
\text { Frequency } \\
\text { Ubiquity }\end{array}$ & $\begin{array}{l}1 \\
<1 \% \\
33 \%\end{array}$ & $\begin{array}{l}16 \\
3 \% \\
75 \%\end{array}$ & $\begin{array}{l}65 \\
11 \% \\
75 \%\end{array}$ & $\begin{array}{l}53 \\
25 \% \\
75 \%\end{array}$ & $\begin{array}{l}135 \\
10 \% \\
55 \%\end{array}$ \\
\hline $\begin{array}{l}\text { Cola cf. nitida } \\
\text { Ubiquity }\end{array}$ & - & $\begin{array}{l}\text { Present } \\
100 \%\end{array}$ & $\begin{array}{l}\text { Present } \\
100 \%\end{array}$ & $\begin{array}{l}\text { Present } \\
100 \%\end{array}$ & $\begin{array}{l}\text { Present } \\
84 \%\end{array}$ \\
\hline $\begin{array}{l}\text { Dacryodes edulis } \\
\text { Ubiquity }\end{array}$ & - & $\begin{array}{l}\text { Present } \\
100 \%\end{array}$ & $\begin{array}{l}\text { Present } \\
100 \%\end{array}$ & $\begin{array}{l}\text { Present } \\
100 \%\end{array}$ & $\begin{array}{l}\text { Present } \\
84 \%\end{array}$ \\
\hline Total number & 108 & 562 & 574 & 181 & 1425 \\
\hline Density (item/liter) & 7.2 & 22.5 & 23 & 7.2 & 14.3 \\
\hline
\end{tabular}

produces elliptical drupes $(\sim 7 \mathrm{~cm}$ long $)$ that ripen to a purple or blue hue, but the edible pulp (mesocarp) is somewhat tough and oily and will soften when boiled. While the endocarp and testa of the stone are thin and unlikely to preserve, the highly convoluted and segmented embryo within it (Fig. 6D) is denser and thus able to survive charring (as in Fig. 6E).

\section{Togu Missiri and the Long-Distance Trade of the Late First and Early Second Millennium AD}

How Did the Tropical Produce Get to Togu Missiri?

The find of kola nut and Safou fruit remains at Togu Missiri raises questions about the circumstances of their deposition. It is not usual to find any botanical trace of kola nuts at the point of consumption since they are reduced to a pulp by chewing and often digested. Further, no durable specialized material culture is currently or historically used in their transport and storage. Kola nuts are usually stored and transported in baskets and wrapped in leaves. Why, then, do we find large fragments of nuts here? We suggest that whole kola nuts or large fragments would only enter the archaeological record in important numbers during the regular process of repacking the nuts and discarding those that are no longer in good condition and risk spoiling others by spreading mold or infestation. If Togu Missiri were a regular halt on the kola trade route northwards, then it would make sense that nuts would regularly be discarded there and that some would survive alongside other organic material 
Fig. 6 Modern Cola sp. and Dacryodes edulis drawings and archaeobotanical remains from Togu Missiri. A Fruit cluster, sectioned fruit, seed and seed sections of Cola acuminata (after Kohler 1890). B and C Archaeobotanical remains, Cola cf. nitida carbonized fruit from Togu Missiri archaeological deposits A14 and A6. D Dacryodes edulis fruit and seeds (after Hooker, 1899). E Archaeobotanical remains, Dacryodes edulis carbonized fruit from Togu Missiri archaeological deposit A17
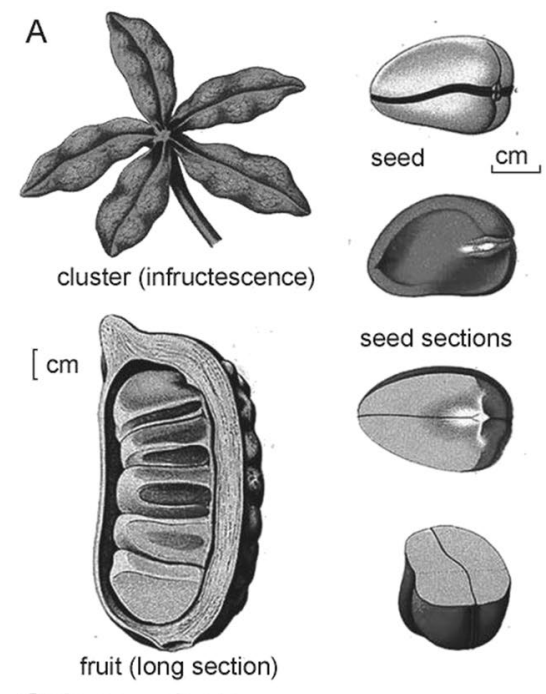

seed sections
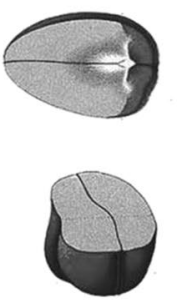

Cola acuminata
B

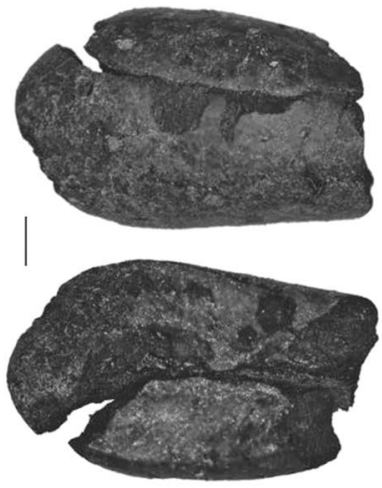

C

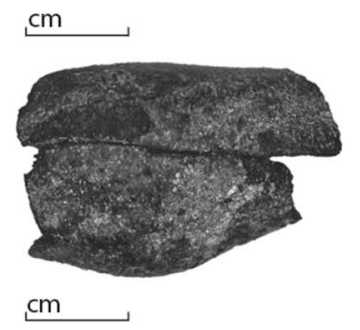

fruit long section

E
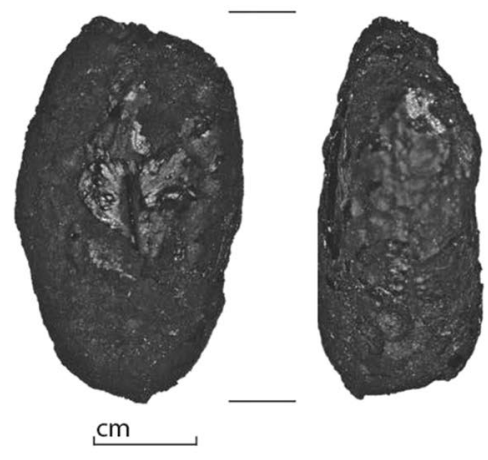

embryo views and section

Dacryodes edulis

in the midden deposits. Their charred state might not be an accident but rather a deliberate burning of infested nuts to prevent the spread of pests, as is also suggested by current best practice guidelines, which advocate burning and burying the discarded nuts (Ndingwan et al., 2013). It is a question of chance that these middens were deposited on the habitation mound and in the area of our excavations. However, the finds do allow us to suggest that Togu Missiri was a settlement through which kola nuts were regularly traded, rather than only being a point where they were consumed.

If Paul Lovejoy's interpretation of the linguistic data is correct and kola trade originated in the Sierra
Leone-Guinea border highlands (Lovejoy, 1980), then the kola nuts would have reached Togu Missiri on a route that roughly follows the course of the Niger. From the mid-eighteenth century onwards, according to Roberts (1987), the kola trade from the Segu area was focused mainly on the trade entrepots of Wassulu and Bonduku, with only a secondary route to Guinea and Sierra Leone. The oral accounts that we have collected also speak of recent trade for kola through entrepots in Côte d'Ivoire, in particular Man, Bouaké, and even Abijan (Fig. 3). Roberts (1987, p. 62) further states that the Maraka kola trade did not often use the river but instead relied on overland caravans for their journeys, which were often more 
than $500 \mathrm{~km}$ one way. In the establishment of early trade from the Guinea highlands to the Middle Niger, prior to the last centuries of the first millennium, it is difficult to imagine that the river would not have played some role in transport or at least in the establishment of contacts between the populations of the two regions. As Kuba (2009) points out, for the lower reaches of the Niger, river trade (at least downstream) was considerably faster, with less need for tolls and negotiations, something that would be convenient for the trade of perishable goods. For now, however, we must treat the question of trade routes as mostly unknown. This is because the northern edges of the forest zone, especially the areas of Guinea and northern Cote d'Ivoire, have seen little archaeological work and no archaeobotanical analyses from this area are known to the authors.

What Was the Wider Trade Network and Who Were the Traders?

Our results suggest that kola nuts were not the only commodities traded north from the forest into the savanna zone. The safou fruit remains found at Togu Missiri shows us two things: Firstly, those trade operations were fast enough to bring tropical fruits northward into the savanna. Secondly, the previous archaeological and historical view on traded items in West Africa was too narrow. The Arabic historical sources with their focus on gold are extremely limited in their information on trade goods in the West African interior. Early European sources contain much more detail for the coastal regions, but not until the fifteenth century. Archaeological research has missed many goods traded across the region because of preservation problems, especially for organic objects. The fortunate finds of kola nut and safou fruits from Togu Missiri strongly suggest that we need to imagine early long-distance trade in West Africa as incorporating a much more diverse range of items than the current historical and archaeological evidence documents.

It is usual for authors on historical trade in West Africa to focus on gold, and as we have stated above, the link between kola and gold trades has been made by Levtzion and R. McIntosh. It is, however, also the case that the early written sources for the area have the gold trade as their main concern. It is perhaps these sources that lead many historians to place a disproportionate emphasis on gold (Green, 2019;
Hunwick et al., 1979) and slaves and to neglect other trade items. A notable exception is Brooks (1993), whose list of traded items is considerably more varied. The archaeological focus has been on gold, salt, iron, stone, cowrie shells, and beads. Some of the less frequently documented trade items include animal hides (Dueppen \& Gokee, 2014) and ivory (Stahl $\&$ Stahl, 2004). However, the accounts collected by Roberts (1987) and the Markadugu project (Gestrich \& Keita, 2017) suggest that the emphasis, at least in recent centuries, was on dried fish, the fermented tree-pod spice sunbala, horses, tobacco, re-exported desert salt, and cotton cloth. From a seventeenthcentury source, we also know that grain was exported from the area of Ségou to Timbuktu (Houdas, 1964, p. 406). Gold is nowhere mentioned, though we do know from Mungo Park (1858) that there was a trade in gold $250 \mathrm{~km}$ further upstream at Kangaba in the late eighteenth century.

On the present evidence, we assume that the population of Togu Missiri was involved in trading forest zone items further northwards, into the Niger's Inland Delta and its margins, and to the desert edge. This trade network intersects with others and feeds into a complex and high-volume network of exchange centered on the middle reaches of the Niger. The oftencited geological and environmental differences in the West African interior appear to have been the basis for the development of high-volume long-distance trade in basic provisions, especially salt and tools, by the mid-first millennium AD. This can be seen from growing imports and less local manufacture in metropolitan areas such as Jenné-jeno (McIntosh, 1995) and increased evidence of large-scale, market-oriented manufacturing in peripheral regions (Gestrich, 2013; Gestrich \& MacDonald, 2018). Long-distance but low-volume trade in nonessential items had existed in the region since the Late Stone Age. That trade was fundamentally different from the highvolume trade that began in the first millennium $\mathrm{AD}$. It included cash crops, large-scale manufacture for export, specialist traders with established networks, and above all, the dependency of large populations on the availability of traded items such as iron tools and grinding stones (for a description of this system of growing specialization and regional interdependency, see R. McIntosh, 1998). Societies along the Niger were already used to buying and selling things regularly by the mid-first millennium $\mathrm{AD}$, probably 
with a socioeconomic system that was sufficiently monetarized to cope with the large scale and high frequency of transactions. The earliest known cowrie shells from the region also date from the midfirst millennium and were clearly used as currency by the beginning of the second millennium (Haour \& Christie, 2019). The regular trade in basic items and the concurrent development of specialist traders and long-distance routes will have opened up the possibility for any item to be traded in any volume along the same routes. The fact that forest zone safou fruits were brought to Togu Missiri, apparently regularly during three centuries, may therefore act as an example of how economically connected the entire interior of West Africa was in the late first and early second millennium AD.

It is, therefore, interesting to note the absence of kola nut and safou remains in the pre-tenth-century layers at Togu, although midden deposits were equally abundant there. Of course, this is not evidence that the trade in kola nuts did not exist during this period, but it might not have had the same volume, or it might not have used Togu Missiri as a regular stop. In any case, we must suppose other items to have traveled along the same routes until a market for kola nuts was established. By then, specialized traders had well-established relationships along their trading routes.

It remains to discuss the sociocultural and economic contexts within which such specialized traders operated. A large number of historical and archaeological writings have focused on the structure of trade in West Africa, emphasizing the establishment of trade diasporas, the importance of shared cults, or a shared and exclusive Muslim identity as key factors in the establishment of trade links (Brooks, 1993; Wilks, 1961). Following Levtzion (1973), these trade diasporas are often linked to the Empire of Ghana and its downfall. This link has become cemented in the historical literature of the area due to the identification of the Ghana of the medieval Arabic sources with the Wagadu polity of Soninké historical traditions (see Gestrich 2018). Across many parts of West Africa, Soninké individuals and communities have functioned as long-distance traders and have set up diaspora communities over a remarkably wide geographic area. Many of them link their existence in diasporic communities to the "scattering" (saanxi) event that marks the fall of Wagadu in oral traditions.
In fact, many local populations regard it as received wisdom that all Soninké are traders. Due to this, it has become usual for authors on the past of Sahelian West Africa to associate all trade with the Soninké, and with the Empire of Ghana, a desert-edge polity engaged in Saharan trade. Both R. McIntosh (1998) and Lovejoy (1980), for example, assume that Soninké networks must be behind the early kola trade. At first glance, our results would support this identification. Togu is, and is claimed to always have been, a settlement of the Maraka population group, and maraka is the Bambara word for those who call themselves Soninké. This has led to the assumption that the Maraka settlements of the Ségu area were founded as part of the Wagadu polity or as part of its dissolution and the scattering of its population (e.g., Pageard, 1961). However, a closer look reveals that the term Maraka nowadays describes people of very varied ethnic backgrounds. They share a certain number of cultural practices, by which their identity is defined in opposition to the Bamana who also settle in this area (Bazin, 1985). A Maraka is supposed to be Muslim, engage in trade, and not take part in wars. For the Maraka of the Ségu area, this is not overtly a profound cultural difference, and becoming Maraka often simply denotes the addition of Islamic religious practices or a change of clothing style (Bazin, 1972). Anyone could and can become Maraka, but men engaging in these activities would have been excluded from their communities of origin to a certain degree. They would no longer have been part of initiation societies, the family farming enterprise, or the strict scheme of succession within the family unit. A male Maraka's work and life are incompatible with male identity in most agricultural societies of Sahelian West Africa, including the Soninké. While the Maraka are known far and wide as traders, engaging in this activity means leaving behind the ties of the sedentary agricultural lineages. The word maraka, for us, thus equates with a set of practices that include, but are not limited to, trade. It has become attached to the Soninké by virtue of the high number of them engaged in commerce.

We have focused on this argument to make explicit that there is no dependable link of the early kola trade to either the Soninké ethnicity or the Wagadu polity/ the Empire of Ghana. Secondly, we want to stress the extent to which traders in Sahelian West Africa were a professional group, yet one with such pronounced 
social distance from others that they could be considered almost like an ethnic group. In contrast to some other West African occupational specialists, membership is open, and there are no strict rules regarding endogamy. The degree to which individuals in such groups engaged in commerce, however, could be highly variable. There were surely those who plied long-distance trade routes several times a year, as well as those for whom joining a trading caravan was a one-off when they found themselves in a position to do so and those who engaged only in resale. We cannot be certain how far back in time Maraka identity existed and whether the inhabitants of Togu Missiri would have understood themselves as being Maraka or even belonging to a trading group, separate from the surrounding population. For the moment, the integration of traders into local society in this area is still an open question, but one we hope to address in future studies.

\section{Conclusions: Early Kola Trade Into the Middle Niger}

Lovejoy's history of the West African kola trade appeared in a themed issue of the Cahiers d'études africaines, alongside an article by Roberts (1980) which criticized some fundamental points of Hopkins' Economic History of West Africa. Hopkins had seen African societies as largely self-sufficient before the nineteenth century, a view that is frequently repeated to this day (e.g., Eltis, 2013), often in the first chapter of historical overviews focused on later periods. For Hopkins, local exchange was limited because everyone was producing the same goods under the same conditions. Long-distance trade, for him, was limited to luxury items destined to individuals with high buying power. In addition to criticizing Hopkins' static picture of the pre-nineteenth-century past, Roberts pointed out that several important long-distance trade goods, such as salt and kola, were accessible to ordinary buyers because the quantities required were small. People bought when they could. He further showed how the market limitations identified by Hopkins were overcome by transporting surpluses into areas beyond the limits of local markets where that product was in demand. He argued that ecological differences strongly influenced precolonial West African trade and that this, in turn, aided specialized production when coupled with long-distance trade. While the four contributions that discussed Lovejoy's and Roberts' papers mainly focused on the role of polities and slavery as depending on or creating trade links, several important further points were raised which continue to be topical now. Amselle (1980), for instance, pointed out the uncertain causality between trade, polity, and slavery and that ecological factors alone were somewhat too weak to explain the development of longdistance trade. According to him, the growers in kolaproducing areas needed to make a conscious decision to plant and tend to the plants, harvest and pack them, and thereby make a seasonally abundant crop of limited sale value into a product for export. At the time, Amselle came to the rather vague conclusion that the West African subcontinental economy was a globalizing system in which everyone had their role to play. Based on the archaeological work of the intervening 40 years and with the arguments presented here, we might add some precision to this debate.

By the end of the first millennium AD, the West African interior was connected by trade routes. These occasionally transported luxury goods but regularly moved all sorts of materials between the different geological and ecological zones. Some of these materials were moved in high volumes. It is now apparent that the environmental differences that Roberts underlined did more than just present opportunities for trade. Rather, they made trade inevitable: there are strong indicators that the large population living in and around the Inland Niger Delta from the mid-first millennium AD would not have covered its needs without a medium- to longdistance, high-volume movement of nonluxury items. The archaeological data indicates that the populations of such ecological and economic niche areas drove high-volume exchange and regional economic specialization and the development of internally differentiated specialized traders and craftspeople. Over time, this had an integrating effect on the broader region and, from the mid-first millennium onward, led to societies in which specialization and the buying and selling of goods were commonplace. The end product is the situation that Amselle described, a globalized economy in which everyone had their place - that is, everyone produced something to sell. Although some communities may have been able to cover their basic needs 
for food, clothing, and shelter, almost all would have also been able, and were willing, to produce something that traders would buy from them on a regular basis.

The find of Cola sp. and Dacryodes edulis remains at Togu Missiri shows that the regional trading networks that included the Middle Niger region were well-organized by the early second millennium and ran from the West African forest zone through the Savanna and Sahara to North Africa. Much research has concentrated on the trans-Saharan portion of this trade, to the detriment of the sub-Saharan portion, though the latter is likely to have been economically far more important. That kola nuts reached Arab traders in Walata in the mid-thirteenth century is a testament to how efficient these networks were (Levtzion \& Hopkins 2000, p. 307). Even more impressive is that fresh tropical fruit appears to have been brought from the forest to at least the southern margins of the Inland Niger Delta.

Previous research on early sub-Saharan trade in West Africa tends to concentrate on archaeologically more visible items such as iron, and on gold destined for North Africa. Other goods are often assumed to have also been part of long-distance trade, such as salt, sandstone, wood, clothing, and slaves. Yet our results show that we must in the future envisage this trade to have incorporated a much larger pallet of perishable items, especially foodstuffs. And in the face of such a regular, highvolume trade, we must also consider the entire subcontinent to have been closely and regularly connected, at least from the late first millennium AD.

Acknowledgements The authors would like to thank the people of Togu for their enthusiastic support for this research. In particular, we thank Seydna Oumar Dembele and his family for being our hosts while in Togu, as well as those who participated in the excavations: Bafing Djiré, Zoumana dit Bagui Djiré, Baba Koita, Ladji Kanouté, Madou dit Fa Dembélé, Bassa Dembélé. We thank David Glauser for his help with the photographs of the archaeobotanical remains. We thank the students of the HOPE lab in Bamako for their help with the flotation of the soil samples.

Funding Open Access funding enabled and organized by Projekt DEAL. The research for this article was carried out as part of the Markadugu Project, funded by the Volkswagen Foundation. The archaeobotanical analyses were carried out at the UCL Institute of Archaeology in London and Goethe University in Frankfurt am Main. The fieldwork was supported by the Institut des Sciences Humaines de Mali and the Université des Sciences Sociales et Gestion in Bamako.

Open Access This article is licensed under a Creative Commons Attribution 4.0 International License, which permits use, sharing, adaptation, distribution and reproduction in any medium or format, as long as you give appropriate credit to the original author(s) and the source, provide a link to the Creative Commons licence, and indicate if changes were made. The images or other third party material in this article are included in the article's Creative Commons licence, unless indicated otherwise in a credit line to the material. If material is not included in the article's Creative Commons licence and your intended use is not permitted by statutory regulation or exceeds the permitted use, you will need to obtain permission directly from the copyright holder. To view a copy of this licence, visit http://creativecommons.org/licenses/by/4.0/.

\section{References}

ANOM 51 PA 1. Notice sur le cercle de Ségou (vers 1893/1894). Archives Nationales d'Outre-Mer, Aix-enProvence. 51 PA 1, ark:/61561/vl918kfz.

Amselle, J.-L. (1980). Autosubsistance, petite production marchande et chaînes de sociétés. Cahiers D'études Africaines, 20(77-78), 155-160.

Bazin, J. (1972). Commerce et predation. L'Etat Bambara de Segou et ses Communautés Marka. Conference on Manding Studies. Royal Anthropological Institute MS415/9. Manuscript.

Bazin, J. (1985). À chacun son Bambara. In J.-L. Amselle \& E. M'Bokolo (Eds.), Au coeur de l'ethnie: Ethnies, tribalisme et état en Afrique (pp. 87-128). Ed. la Découverte.

Bazin, J. (1988). Princes désarmés, corps dangereux: Les "Rois-Femmes" de La région de Segu. Cahiers D'études Africaines, 28(111/112), 375-441.

Bertaux, C. (1984). La technique des prescriptions sacrificielles dans la géomancie bambara (région de Ségou, Mali). Systèmes De Pensée En Afrique Noire, 6, 117-130.

Blench, R. M. (2006). Archaeology, language, and the African past. AltaMira.

Bostoen, K. (2014). Wild trees in the subsistence economy of early Bantu speech communities. In C. J. Stevens, S. Nixon, M. A. Murray, \& D. Q. Fuller (Eds.), Archaeology of African plant use (pp. 129-140). Left Coast Press.

Boujou, J. (2000). Clientélisme, corruption et gouvernance locale à Mopti (Mali). Autrepart, 14, 143-163.

Brooks, G. E. (1980). Kola trade and state-building: Upper Guinea coast and Senegambia, $15^{\text {th }}-17^{\text {th }}$ centuries. Working Papers in African Studies, No. 38. Boston: African Studies Center. https://hdl.handle.net/2144/40581. Accessed 20 June 2021.

Brooks, G. E. (1993). Landlords and strangers. Westview Press.

Burdock, G. A., Carabin, I. G., \& Crincoli, C. M. (2009). Safety assessment of kola nut extract as a food ingredient. Food and Chemical Toxicology, 47, 1725-1732.

Burkill, H. M. (2000). Useful plants of West Tropical Africa (2nd ed.). Kew Publishing. 
Champion, L. (2019). The evolution of agriculture, food and drink in the ancient Niger River basin: Archaeobotanical studies from Mali and Benin. Ph.D. thesis, University College London, London.

Champion, L., \& Fuller, D.Q. (2019). Archaeobotany: Methods. In Spear, T. (Ed.), The Oxford encyclopedia of African historiography: Methods and sources. Vol 1. Oxford: Oxford University Press.

Dah-Nouvlessounon, D., Adoukonou-Sagbadja, H., Nafan, D., Adjanohoun, A., Noumavo, P. A., Sina, H., et al. (2016). Morpho-agronomic variability of three kola trees accessions [Cola nitida (Vent.) Schott et Endl., Cola acuminata (P. Beauv.) Schott et Endl., and Garcinia kola Heckel] from Southern Benin. Genetic resources and crop evolution, 63(3), 561-579.

Drucker-Brown, S. (1995). The court and the kola nut: Wooing and witnessing in Northern Ghana. The Journal of the Royal Anthropological Institute, 1(1), 129-143.

Dueppen, S. A., \& Gokee, C. (2014). Hunting on the margins of medieval West African states: A preliminary study of the zooarchaeological record at Diouboye, Senegal. Azania: Archaeological Research in Africa, 49(3), 354-385.

Eltis, D. (2013). The slave trade and commercial agriculture in an African context. In R. Law, S. Schwarz, \& S. Strickrodt (Eds.), Commercial agriculture, the slave trade and slavery in Atlantic Africa (pp. 28-53). Boydell \& Brewer.

Houdas, O. (Ed.) (1964). Tarikh es-Soudan: Par Abderrahman b. Abdallah b. 'Imran b. 'Amir es-Sa'di. Adrien-Maisonneuve.

Genequand, D., Apoh, W., Gavua, K., Canetti, M., Champion, L., Gyam, S., Hajdas, I., Maret, F., de Reynier, C., \& Ruben, I. (2020). Preliminary report on the 2019 season of the Gonja Project, Ghana. SLSA Jahresbericht, 2019, 225-289.

Gestrich, N. (2013). The archaeology of social organisation at Tongo Maaré Diabal. Ph.D. thesis. University College London, London.

Gestrich, N. (2019). The empire of Ghana. In Spear, T. (Ed.), Oxford research encyclopedia of African history. Oxford University Press. https://doi.org/10.1093/acrefore/97801 90277734.013.396.

Gestrich, N., \& Keita, D. (2017). Report on a season of prospection and excavation near Ségu, Mali. Nyame Akuma, 88, 48-55.

Gestrich, N., \& MacDonald, K. C. (2018). On the margins of Ghana and Kawkaw: Four seasons of excavation at Tongo Maaré Diabal (AD 500-1150), Mali. Journal of African Archaeology, 16, 1-30.

Green, T. (2019). A fistful of shells. University of Chicago Press.

Håland, R. (1980). Man’s role in the changing habitat of Méma during the old Kingdom of Ghana. Norwegian Archaeological Review, 13, 31-46.

Haour, A., \& Christie, A. (2019). Cowries in the archaeology of West Africa: The present picture. Azania: Archaeological Research in Africa, 54, 287-321.

Hauenstein, A. (1974). La noix de cola. Coutumes et rites de quelques ethnies de Côte d'lvoire. Anthropos, 69(3/4), 457-493.

Hooker, W. J. (1899). Icones Plantarum, Vol. 26. Dulau and Co.
Hopkins, A. G. (2016). An economic history of West Africa. 2nd edition. Routledge.

Hunwick, J. O. (1973). The mid-fourteenth century capital of Mali. The Journal of African History, 14, 195-206.

Hunwick, J. O., Meillassoux, C., \& Triaud, J.-L. (1979). La géographie du Soudan d'après al-Bakri Trois Lectures. Revue Française D'histoire D'outre-Mer, 66, 111-138.

Interviews Markadugu Project (2016). Group interview with village council at Togu, 13/12/2016. Group interview with village council at Marakaduguba, 14/12/2016. Interviews conducted by Seydou Camara, Soumaila Coulibaly, Daouda Keita and Nikolas Gestrich.

Kirikoshi, H. (2019). Migrants' participation in cocoa production: Trust-building among multi-ethnic groups in West Africa. In H. Kirikoshi, Y. Matsunami, \& S. Takeuchi (Eds.), Development, migration, and resources in Africa (pp. 45-59). ASC-TUFS Working Papers.

Köhler, H. A. (1890). Medizinal-Pflanzen, Vol. 2. Franz Eugen Köhler.

Kuba, R. (2009). Cultural contacts between the savannah and the forest: Trade along the Eastern Niger. In S. Magnavita, L. Koté, P. Breunig, \& O. A. Idé (Eds.), Crossroads/Carrefour Sahel: Cultural and technological developments in first millennium BC West Africa (pp. 147-156). Journal of African Archaeology Monograph Series 2. Africa Magna.

Kwame, A. (2019). An ethnographic sketch of social interactions in Dagbon society: The case of greeting, sharing drinks and kola nut. Journal of Multidisciplinary Research at Trent, 2(1), 1-20.

Levtzion, N. (1973). Ancient Ghana and Mali. Methuen.

Levtzion, N., \& Hopkins, J. F. P. (Eds.) (2000). Corpus of early Arabic sources for West African history. Markus Wiener.

Lovejoy, P. E. (1980). Kola in the history of West Africa. Cahiers D'études Africaines, 20(77-78), 97-134.

Lovejoy, P. E. (1995). Kola Nuts. The 'coffee' of the central Sudan. In Goodman, J., Lovejoy, P. E., \& Sherratt, A. (Eds.), Consuming habits. Drugs in history and anthropology (pp.103-125). Routledge.

MacDonald, K. C., \& Camara, S. (2011). Segou: Warfare and the origins of a state of slavery. In P. Lane \& K. C. MacDonald (Eds.), Slavery in Africa. Archaeology and memory (pp. 25-46). Proceedings of the British Academy 168.

MacDonald, K. C., Camara, S., Canós-Donnay, S., Gestrich, N., \& Keita, D. (2011). Sorotomo: A forgotten Malian capital? Archaeology International, 13(14), 52-64.

MacDonald, K. C., Gestrich, N. , Camara, S., \& Keita, D. (2018). The 'Pays Dô' and the origins of the empire of Mali. In T. Green \& B. Rossi (Eds.), Landscapes, sources and intellectual projects of the West African past: Essays in honour of Paulo Fernando de Moraes Farias (pp. 63-87). Brill.

McIntosh, R. J. (1998). The peoples of the Middle Niger. Blackwell Publishers.

McIntosh, S. K. (Ed.). (1995). Excavations at Jenne-Jeno, Hambarketolo and Kaniana (Inland Niger Delta, Mali), the 1981 Season. University of California Press. 
Meillassoux, C. (1973). Etat et conditions des esclaves a Gumbu (Mali) au XIXe Siecle. The Journal of African History, 14(3), 429-452.

Ndingwan, M. A., Tsobeng, A., Asaah, E., Degrande, A., \& Tchoundjeu, Z. (2013). Best practices on kola nut conservation and storage. Handbook for Kola producers. World Agroforestry Centre.

Niemenak, N., Onomo, P. E., Lieberei, R., \& Ndoumou, D. O. (2008). Purine alkaloids and phenolic compounds in three Cola species and Garcinia kola grown in Cameroon. South African Journal of Botany, 74(4), 629-638.

Nixon, S. (2017). Trans-Saharan gold trade in pre-modern times: Available evidence and research agendas. In D. J. Mattingly, V. Leitch, C. N. Duckworth, A. Cuénod, M. Sterry, \& F. Cole (Eds.), Trade in the ancient Sahara and beyond (pp. 156-188). Cambridge University Press.

Nyadanu, D., Lowor, S. T., Akpertey, A., Tchokponhoué, D. A., Pobee, P., Dogbatse J. A., et al. (2020). Genetic variability of bioactive compounds and selection for nutraceutical quality in kola [Cola nitida (Vent) Schott. and Endl.]. PLoS ONE, 15(12): e0242972

Park, M. (1858). Travels in the interior of Africa. A. and C. Black.

Pageard, R. (1961). Note sur le peuplement du pays de Ségou. Journal De La Société Des Africanistes, 31, 83-90.

Person, Y. (1986). Samori: Une révolution dyula. Vol. 1. Dakar: IFAN.
Roberts, R. (1980). Linkages and multiplier effects in the ecologically specialized trade of precolonial West Africa. Cahiers D'études Africaines, 20(77-78), 135-148.

Roberts, R. (1987). Warriors, merchants, and slaves: The state and the economy in the Middle Niger Valley, 1700-1914. Stanford University Press.

Serneels, V., \& Perret, S. (2003). Quantification of smithing activities based on the investigation of slag and other material remains. In Archaeometallurgy in Europe. Proceedings of the International Conference (Milano, September 24-26, 2003), 469-478.

Stahl, A. B., \& Stahl, P. (2004). Ivory production \& consumption in Ghana in the early second millennium AD. Antiquity, 78, 86-101.

Sundström, L. (1966). The cola nut: Functions in West African social life. Studia Ethnographica Uppsaliensia XXVI, Varia, II, 135-149.

Tridge, n.d. https://www.tridge.com/intelligences/kola-nut/ production. Accessed 09 Mar 2020.

Wilks, I. (1961). The northern factor in Ashanti History: Begho and the Mande. The Journal of African History, 2(1), 25-34.

Publisher's Note Springer Nature remains neutral with regard to jurisdictional claims in published maps and institutional affiliations. 